\title{
Inglefield Land 1995: geological and economic reconnaissance in North-West Greenland
}

\author{
Bjørn Thomassen and Peter R. Dawes
}

Field work in Inglefield Land, North-West Greenland in 1995 (Figs 1, 2) was a direct result of an airborne magnetic and electromagnetic survey - project AEM Greenland 1994 (Stemp \& Thorning, 1995a, b), the results of which stimulated considerable economic interest in the region. This survey not only delineated a large number of magnetic and electromagnetic anomalies (Fig. 3) in the Precambrian basement indicating a potential for massive sulphide mineralisation, but through video application it also drew attention to dark coloured, circular structures in central Inglefield Land. These structures were originally recognised during photogeological studies by RTZ Mining and Exploration Limited (Sharp, 1991). The recognition that the circular features formed a well-defined belt started fervent speculation that they might represent a volcanic pipe swarm (Bengaard, 1995; Stemp \& Thorning, 1995a). The geophysical data and the region's potential for kimberlite pipes, created considerable interest from the international mining industry (Minex, 1995a) and commercial exploration under new exploration licences was undertaken in 1995 (Coppard, 1996).

With this background it was felt that the state should monitor the exploration developments in Inglefield Land, and consequently the Government of Greenland, Minerals Office agreed to fund a 4 million kr. follow-up project. This project, carried out by the Geological Survey of Denmark and Greenland, had the main objectives of explaining the geophysical anomalies and circular structures. Apart from the study of the latter, the field work comprised locating selected anomalies by GPS navigation and relating the sites to the regional geology, as well as ore geological studies and geochemical mapping.

This paper describes the field campaign in Inglefield Land and the general geological results obtained. The circular structures were proved to be surficial deposits by RTZ Mining and Exploration Ltd (Coppard, 1996), an interpretation confirmed by our study of the features (Appel, this report).

\section{Logistics}

Inglefield Land is an uninhabited $7000 \mathrm{~km}^{2}$ area situated some $100 \mathrm{~km}$ north of Qaanaaq (Danish Thule) and $200 \mathrm{~km}$ north of Thule Air Base (Pituffik; Fig. 2). It is bordered by the Inland Ice to the south and east, and by Nares Strait to the north and west. Geomorphologically, the area forms a gently northwards dipping plateau of rolling relief dissected by streams running from the Inland Ice to the sea. There are no permanent ice caps but extensive areas are covered by glacial drift that is especially profuse in southern parts.

Mobilisation for the field work was through Thule Air Base. The lack of a suitable, centrally placed site with fixedwing aircraft landing facilities demanded aerial reconnaissance by Twin Otter in early July prior to the geological work. An excellent locality was found on a large, vegetationcovered sand terrace south of the eastern lake of Septembersøerne in eastern Inglefield Land $\left(78^{\circ} 50.60^{\prime} \mathrm{N}, 67^{\circ} 18.03^{\prime} \mathrm{W}\right)$. A $250 \mathrm{~m}$ long strip was prepared and during the following week equipment and fuel were flown in and a tent base camp erected (Fig. 1). Five geologists, three assistants, and a helicopter pilot and mechanic made up the field party. Demobilisation in mid-August was by helicopter via Qaanaaq; the landing strip markings and a small depot of jet fuel remain on site.

\section{Field work}

The field work, carried out by three teams during a fiveweek period of excellent weather, was by helicopter reconnaissance supplemented by traverses from fly camps.

One team, concentrating on the Precambrian shield terrain, combined a check of selected geophysical anomalies with a reconnaissance of the regional geology and mineralisation. A photogeological map at 1:100 000, and geophysical maps from project AEM Greenland 1994 formed the basis for this work (Bengaard, 1995; Stemp \& Thorning, 1995a).

A second team studied the circular structures (Appel, this report) and later investigated a number of magnetic anomalies and rust zones.

A third team carried out a geochemical programme that spanned eleven days of intensive, helicopter-supported systematic stream sediment and stream water sampling with an average sample density of 1 per $25 \mathrm{~km}^{2}$. Soil was collected as a substitute medium in areas without streams. Major and trace element analyses are reported by Steenfelt \& Dam (in press). 


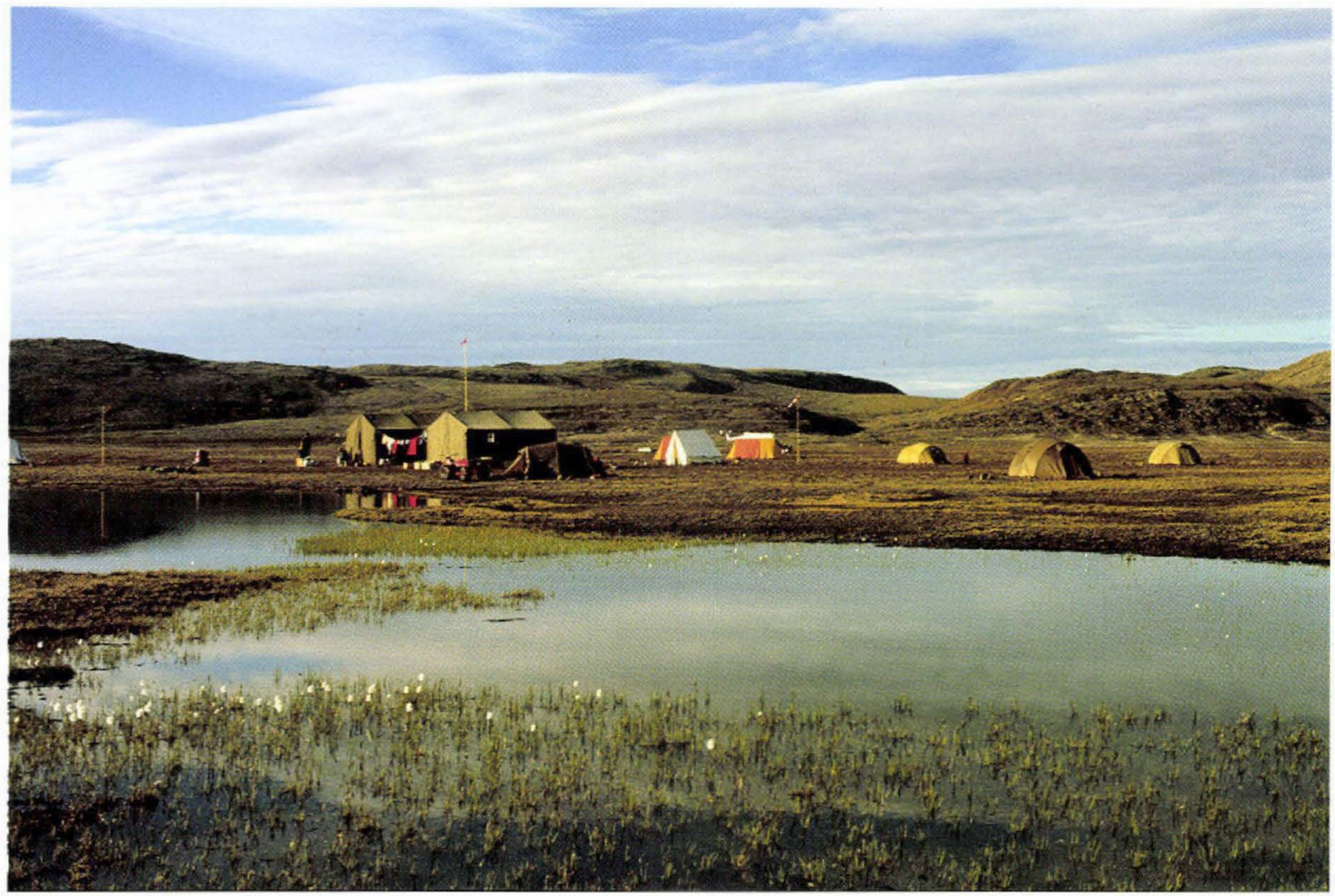

Fig. 1. The Survey base camp south of Septembersøerne seen from the west; orange gossan visible in right background.

\section{Bedrock geology}

The earliest regional geological investigation of Inglefield Land was carried out between 1917 and 1922 (Koch, $1920,1933)$. Koch distinguished the main geological elements of the region: a Precambrian crystalline basement of varied lithology overlain by a undeformed Proterozoic and Lower Palaeozoic cover restricted to the outer coast. $\mathrm{He}$ also noted the large stretches covered by glacial drift in central and southern parts of Inglefield Land (Fig. 2).

Apart from sporadic visits to inland areas by way of the Inland Ice from the Thule district, early work was concentrated on coastal districts, particularly on the sedimentary cover rocks (Troelsen, 1950; Cowie, 1961; Dawes, 1972; Peel et al., 1982). Information on the Precambrian shield remained very sporadic, and the summaries published (Dawes, 1976; 1988) were based essentially on the coastal areas of south-western Inglefield Land between Kap Alexander and Rensselaer Bugt. Apart from a few studies carried out by commercial companies (see below under 'Mineralisation'), the 1995 helicopter reconnaissance of Inglefield Land was the first regional appraisal of the Precambrian shield.

Three main complexes make up the shield: the Etah
Group supracrustal rocks, the Etah meta-igneous complex and a variable gneiss group. All three complexes show wide lithological diversity and they have been metamorphosed under high amphibolite to granulite facies conditions.

The Etah Group is composed of marble, calc-silicate rocks, pelitic schists and gneisses, and psammitic rocks including siliceous garnet gneisses. Metasediments in conspicuous linear tracts dominate the geology in southwestern Inglefield Land. The Etah Group, that is also present in Ellesmere Island, Canada, is of Early Proterozoic (Late Aphebian) or Archaean age.

The Etah meta-igneous complex is a multiphase plutonic suite containing a range from ultramafic and basic rocks to syenites and granites. The complex, also present in neighbouring areas of Canada, has yielded Early Proterozoic ages from 1960 Ma to $1850 \mathrm{Ma}$ (Dawes et al., 1988; Frisch \& Hunt, 1988).

The variable gneiss group contains both paragneisses and orthogneisses, derived from the above-mentioned complexes, as well as other migmatitic rocks. Quartzo-feldspathic, garnet (-sillimanite) gneisses outcropping over large areas of central and eastern Inglefield Land are part of this group. Some of the gneisses are of Early Proterozoic age, but it is unknown whether older material is also represented. 


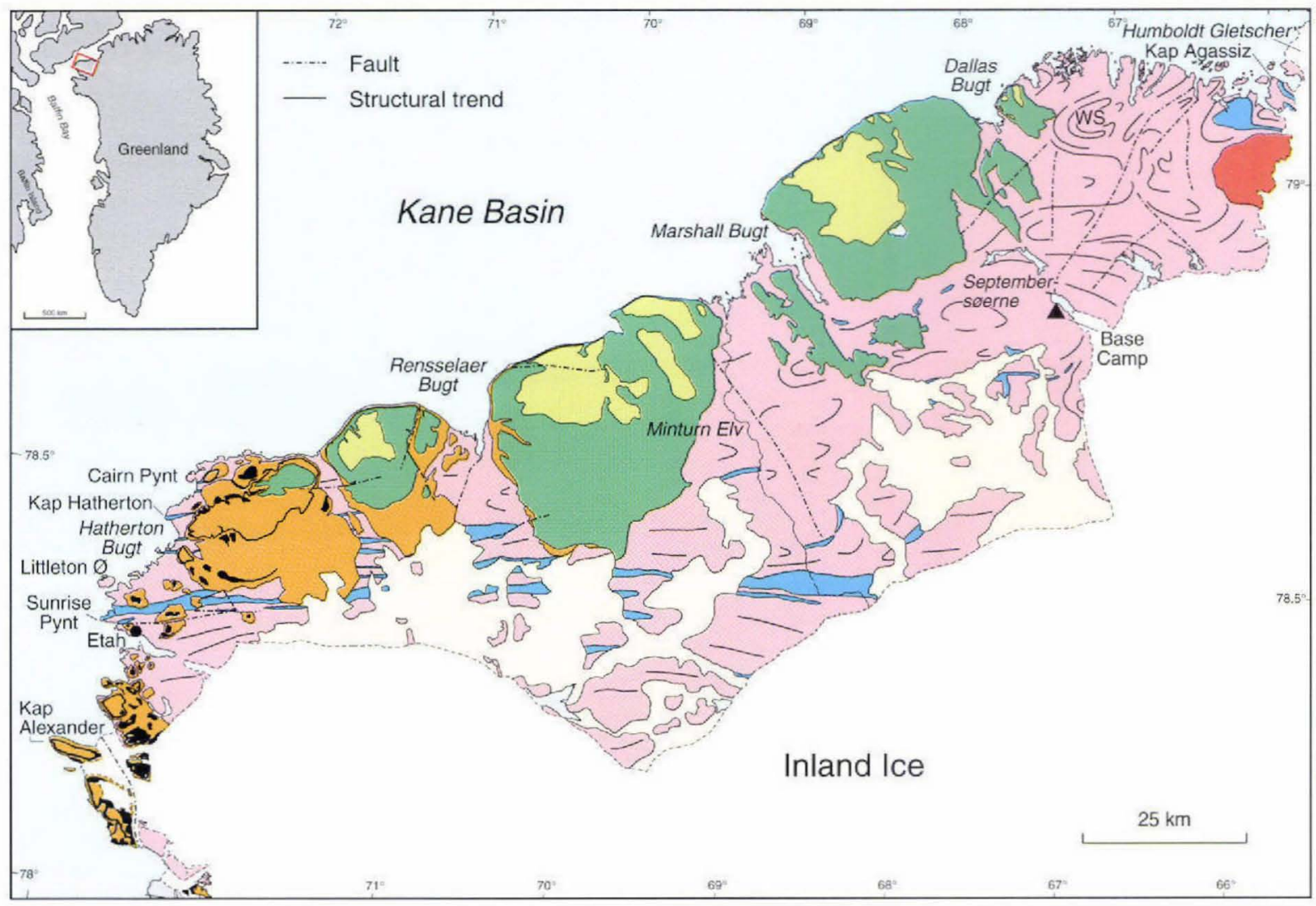

QUATERNARY

Undifferentiated surficial deposits

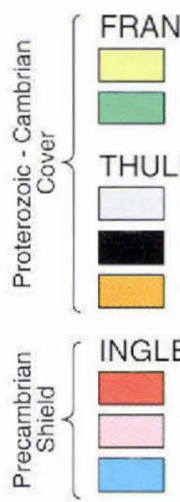

FRANKLINIAN BASIN, mainly Ryder Gletscher Group

Middle to Upper Cambrian, carbonates

Lower to Middle Cambrian, basal siliciclastics, carbonates

THULE BASIN, Thule Supergroup

Late Proterozoic siliciclastics (Hadrynian)

Middle Proterozoic basaltic sills (Neohelikian)

Middle Proterozoic siliciclastics, minor carbonates (Neohelikian)
EFIELD MOBILE BELT, Early Proterozoic (? with Archaean)
Late granite
Etah meta-igneous complex, paragneiss, orthogneiss
Etah Group, marble-rich supracrustal rocks

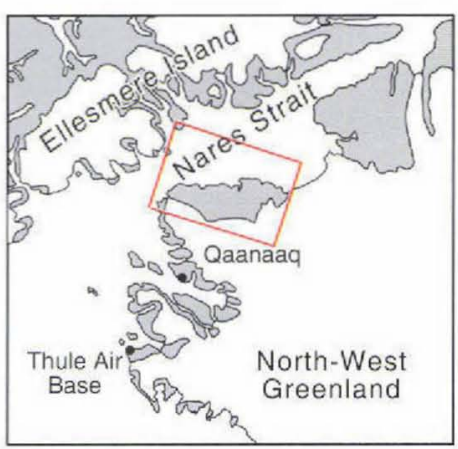

Fig. 2. Geological map of Inglefield Land. WS: 'Wulff structure'.
The 1995 field work demonstrated that the three complexes, all well known from south-western Inglefield Land and part of a regionally conspicuous linear belt, can be recognised farther eastwards across Inglefield Land to Humboldt Gletscher. Thus, the spectacular cliff section at Sunrise Pynt across the steeply-dipping linear belt of metasediments and igneous rocks, that has been used to illustrate the regional geology (Dawes, 1976, fig. 228; Dawes, 1988, fig. 3), has a counterpart in north-eastern Inglefield Land at Kap Agassiz (Fig. 4A). Here highly-deformed pale marble and calc-silicate rocks of the Etah Group are intruded by less-deformed grey and red granite sheets and younger dykes of the Etah meta-igneous complex. Marbledominated supracrustal rocks form several such outcrops south-east and south-west of Kap Agassiz (Fig. 2). The encroachment of metasedimentary rocks by igneous rocks occurs on all scales. Thus, marble and calc-silicate rocks occur as part of coherent supracrustal belts, as well as as isolated tracts and inclusions within igneous rocks.

A glance at the geological map (Fig. 2) shows that, in 


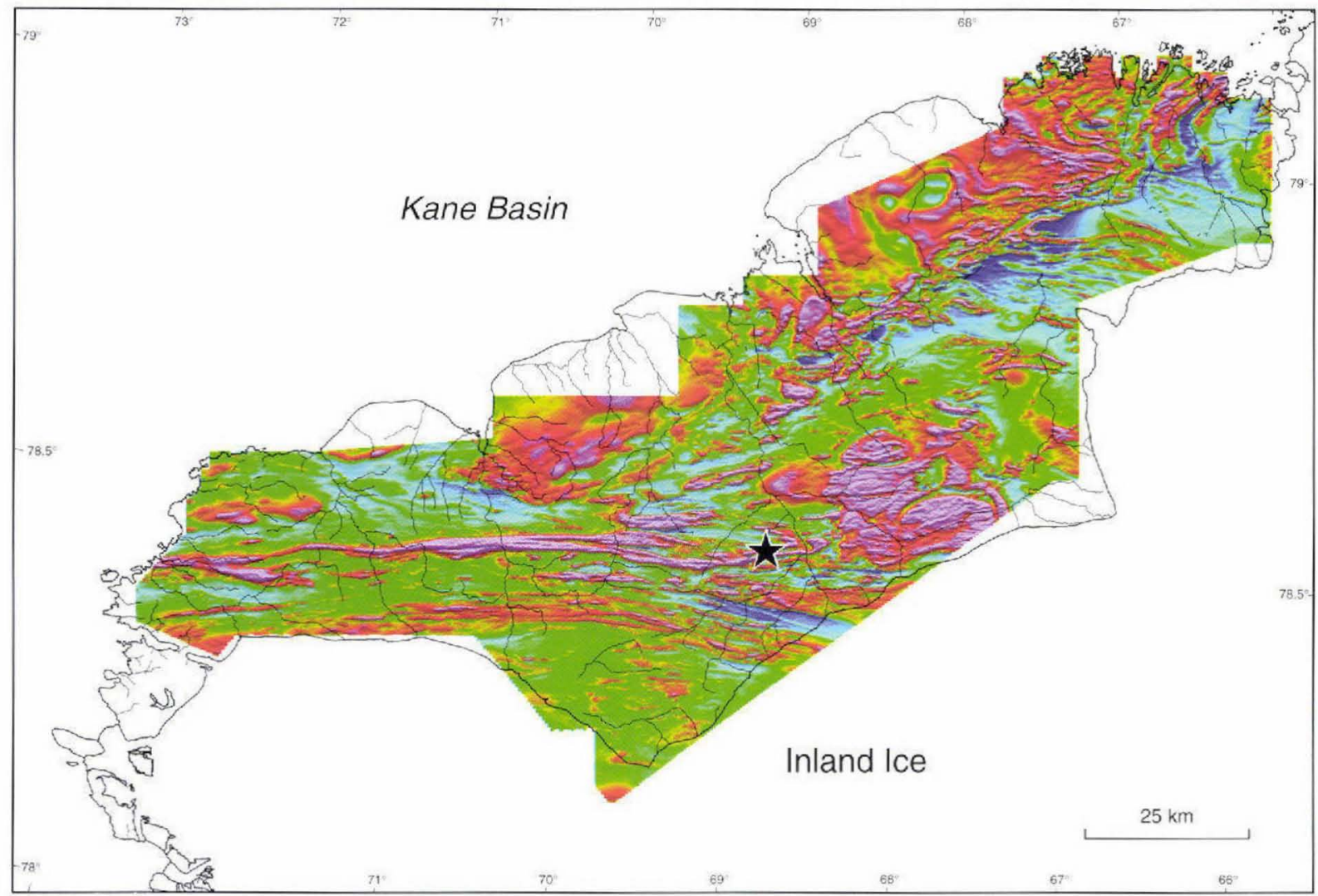

Fig. 3. Residual intensity magnetic anomaly map for part of Inglefield Land. The strongest magnetic anomaly in the area is indicated by a star. Modified from Appel et al. (1995).

contrast to south-western and north-eastern areas, much of central Inglefield Land - the hinterland of Marshall Bugt and Dallas Bugt - lacks conspicuous marble-dominated supracrustal rocks. In this area, multiphase magmatic rocks of the Etah meta-igneous complex dominate, and these rocks have been involved in polyphase deformation that has produced complex fold patterns such as the 'Wulff structure' (Fig. 2). The 1995 observations show that marble and calc-silicate rocks form small, scattered outcrops throughout this central region; their broken-up and isolated form is due to disintegration and assimilation by magmatic rocks.

It has been suggested that the Precambrian shield of Inglefield Land is composed of two distinct rock complexes: a southern one characterised by marble-dominated supracrustal belts and recessive gneisses, and a northern, homogeneous complex of resistant gneisses and granites with minor supracrustal rocks (Bengaard, 1995). This model, that hints at the possibility of two terranes separated by a discontinuous belt of granitoid rocks, is not supported by earlier observations, nor by the 1995 field work or the geophysical data (R. W. Stemp, personal communication, 1995). Marble-rich supracrustal rocks having the same relation- ships to igneous rocks occur both in the northern and southern areas. Along the well-known south-western coast of Inglefield Land (Frisch \& Dawes, 1982), this speculative boundary is drawn by Bengaard (1995, fig. 1) north of the major marble unit at Kap Hatherton. However, the presence of known marble units intruded by the same red granitic rocks as along the coast north of Kap Hatherton (one marble unit is included by Bengaard), militates against any fundamental break in the geology between Etah and Cairn Pynt.

Bengaard's (1995) 'boundary granite suite' comprises pale weathering, fairly homogenous garnet granitic gneisses, a variant of the widespread quartzo-feldspathic paragneisses or the garnet granulites of Sharp (1991). Many of the light-coloured rocks, interpreted photogeologically by Bengaard as marbles, are pale-weathering granites and leucogranites, or darker rocks covered by pale-coloured glacial drift. This applies to large tracts in south-western and southern Inglefield Land, shown by Bengaard (1995) as composing the southern part of the linear belt, and also areas to the south as far as the Inland Ice.

Other discoveries made during the 1995 field work were that large areas of meta-igneous rocks and orthogneisses 
in central Inglefield Land, east and west of Minturn Elv, contain important basic, intermediate and syenitic components. They are reflected on the aeromagnetic map (Fig. 3) as a large positive anomaly interpreted to represent basic igneous bodies by Bengaard (1995). A post-tectonic porphyritic granite massif with relatively low magnetic response occurs adjacent to the Inland Ice, south of Kap Agassiz (Figs 2, 3). The latter can hardly be claimed as a discovery: Koch (1920) shows an intrusive mass in this area on his initial geological map (see also Koch, 1933, p. 13).

The rocks of the Etah meta-igneous complex often contain appreciable amounts of magnetite, and most of the regional magnetic anomalies seem to be attached to rocks of this complex (Fig. 3). The electromagnetic anomalies are largely connected to a unit of grey paragneisses with variable contents of garnet, biotite, graphite and pyrrhotite which cover large parts of central and northern Inglefield Land, and include some of the granitoid rocks of Bengaard (1995).

\section{Mineralisation}

Reconnaissance-type mineral exploration was carried out in Inglefield Land in the period 1969-1973 by Greenaretic Consortium and Internationalt Mineselskab A/S and again two decades later in 1991 and 1995 by RTZ Mining and Exploration Limited. This work concentrated on the investigation of conspicuous gossans caused by iron sulphides that occur in the crystalline basement rocks. Mineralised surface samples showed elevated trace amounts of gold and base metals: max. $207 \mathrm{ppb} \mathrm{Au}, 3767$ ppm Cu, 2565 ppm Zn, 960 ppm Ni (Sharp, 1991).

The mineralisation sites investigated by the Survey in 1995 fall conveniently into two main groups: (1) sulphide mineralisation, characterised by pyrrhotite with minor pyrite and traces of chalcopyrite; and (2) oxide mineralisation dominated by magnetite. The two groups may be intermixed.

\section{Sulphide mineralisation}

Sulphide mineralisation is widespread in central and north-eastern Inglefield Land as revealed by impressive red and yellow gossans which often stretch over several kilometres (Fig. 4B). These gossans are formed by deep weathering of sulphides, typically hosted by graphitic grey gneisses, and clearly registered on the geophysical maps as electromagnetic anomalies. The sulphides are mainly disseminated, but massive lenses of metre size do occur. Gold and base metal contents so far recorded are relatively low (max. $36 \mathrm{ppb} \mathrm{Au}, 980 \mathrm{ppm} \mathrm{Cu}, 2935 \mathrm{ppm} \mathrm{Zn}$ and $276 \mathrm{ppm}$ $\mathrm{Ni}$ in 23 samples). Scattered outcrops of similar sulphide mineralisation were also observed along the south-west Inglefield Land coast (max. $1134 \mathrm{ppb} \mathrm{Au}, 1014$ ppm Cu,
$124 \mathrm{ppm} \mathrm{Zn}$ and $386 \mathrm{ppm} \mathrm{Ni}$ in four samples). Furthermore, sulphide gossans in gneiss related to amphibolite occur in a NE-trending belt north of Septembersøerne. Parts of this belt are relatively rich in pyrite and show slightly elevated gold-base metal contents (max. $294 \mathrm{ppb} \mathrm{Au}, 4216 \mathrm{ppm} \mathrm{Cu}$, $345 \mathrm{ppm} \mathrm{Zn}$ and $219 \mathrm{ppm} \mathrm{Ni}$ in six samples). The origin of the mineralisation is not obvious. The graphite of the host gneisses indicates a marine origin, perhaps as cherty, sulphidic iron formations, whereas the occurrence of rounded quartz grains in massive sulphides points towards a formation by sulphurisation of heavy mineral lenses in a clastic succession.

Minor sulphide mineralisation, revealed by malachite staining, occurs in gneisses at gneiss-marble contacts. At the best investigated locality, $c .9 \mathrm{~km}$ south-west of Kap Agassiz, such mineralisation was followed for over $300 \mathrm{~m}$ along strike. Two chip samples averaged $36 \mathrm{ppb}$ Au and $2382 \mathrm{ppm}$ Cu over $0.8 \mathrm{~m}$, whereas four grab samples contained up to $1188 \mathrm{ppb} \mathrm{Au}$ and $1.3 \% \mathrm{Cu}$. Furthermore, scattered, disseminated sulphides have been observed in mafic-ultramafic rocks and in a few quartz veins of decimetre thickness. Sulphides hosted by a 5-10 $\mathrm{m}$ thick pelite unit of probable basal Cambrian age have been reported from Marshall Bugt by Coppard (1996).

\section{Oxide mineralisation}

Magnetite is widespread in the felsic, mafic and ultramafic rocks of the Etah meta-igneous complex. The most distinct magnetic anomaly on Inglefield Land, situated at Minturn Elv, was found to be related to lenses of magnetite hosted by amphibolitic and ultramafic rocks (Fig. 3). Up to $20 \mathrm{~cm}$ thick lenses of massive magnetite, with minor spinel and olivine, were observed in outcrop, and modelling of the airborne geophysical data suggests that they may reach thicknesses of $200-300 \mathrm{~m}$ in areas completely covered by overburden. Preliminary investigations of samples from outcrop and extensive, magnetite-rich boulder fields indicate contents of up to $0.26 \% \mathrm{~V}_{2} 0_{5}$ and $0.1 \% \mathrm{Ni}$ (Appel et al., 1995).

\section{Concluding remarks}

The field work provided for a regional reconnaissance and appraisal of the main lithologies of the Precambrian shield: a major step forward in compilation of map sheet 6 of the 1:500 000 map series, covering North-West Greenland. The geochemical survey has contributed to the systematic geochemical mapping of Greenland (Steenfelt, 1993).

Most of the abundant and distinct electromagnetic anomalies detected by the airborne geophysical survey stem from a graphitic and sulphidic gneiss unit, wherein no significant amounts of gold or base metals were detected. It 

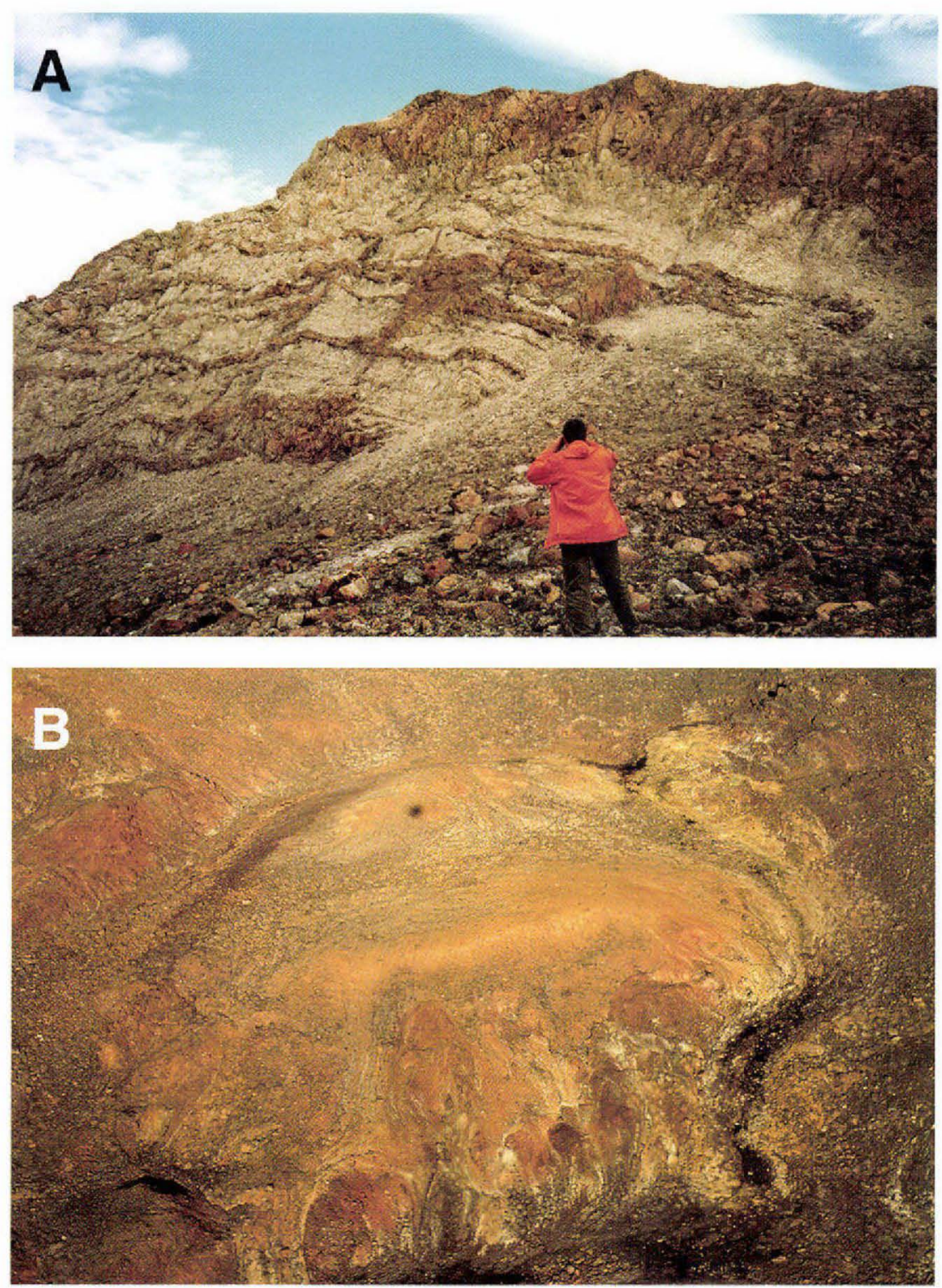

Fig. 4. A:Marble and calc-silicate rocks (pale) of the Etah Group invaded by granitic sheets and dykes (brown) of the Early Proterozoic Etah meta-igneous complex. South of Kap Agassiz, north-eastern Inglefield Land. Height of section about $200 \mathrm{~m}$. B: Typical rust zone in central Inglefield Land seen from the air (helicopter shadow for scale). should, however, be stressed that, because of the deep weathering and frequent extensive moraine cover of the anomalous sites, a serious check of their economic potential should involve detailed geochemistry, ground geophysics and drilling. Magmatic magnetite occurrences with a significant tonnage potential have been demonstrated around Minturn Elv.

Seen against the considerable speculation and interest that the photographically defined circular structures were volcanic pipes (Bengaard, 1995; Stemp \& Thorning, 1995a; Minex 1995b), an origin as surficial features is disappointing (Coppard, 1996; Appel, this report). However, it is the correlation with Canadian geology and the known kim- berlite occurrences there that pierce the Proterozoic Lower Palaeozoic platform strata (not the Inglefield Land circular structures) that initially designated northern Greenland as a prospective kimberlite exploration target (Dawes, 1994). This potential remains.

Acknowledgements. Erik Thomsen and his staff at the Danish Liaison Office at Thule Air Base, Hans Jensen, Hotel Qaanaaq and Rene Forsberg of the National Survey and Cadastre, are thanked for help with logistics; Greenlandair A/S helicopter crew Aviram Harel and Viggo Sørensen were pleasant field companions; and Hauge Andersson of the Danish Polar Center is thanked for a pre-season photographic study of possible landing sites. 


\section{References}

Appel, P. W. U., Dawes, P. R., Schønwandt, H. K., Thomassen, B. \& Thorning, L. 1995: The Minturn Elv magnetite occurrence, Inglefield Land, North-West Greenland. Open File Ser. Grønlands geol. Unders. 95/14, 14 pp.

Bengaard, H.-J. 1995: Photogeological interpretation of Inglefield Land, North-West Greenland. Open File Ser. Gronlands geol. Unders. 95/4, 21 pp.

Coppard, J. 1996: Inglefield Land, exclusive exploration licence 11/95. 1995 year end report. Unpubl. report, RTZ Mining and Exploration Limited, 12 pp.

Cowie, J. W. 1961: Contributions to the geology of North Greenland. Meddr Gronland 164(3), $47 \mathrm{pp}$.

Dawes, P. R. 1972: Precambrian crystalline rocks and younger sediments in the Thule district, North Greenland. Rapp. Gronlands geol. Unders. 45, 10-15.

Dawes, P. R. 1976: Precambrian to Tertiary of northern Greenland. In Escher, A. \& Watt, W. S. (ed.) Geology of Greenland, 248-303. Copenhagen: Geol. Surv. Greenland.

Dawes, P. R. 1988: Etah meta-igneous complex and the Wulff structure: Proterozoic magmatism and deformation in Inglefield Land, North-West Greenland. Rapp. Grønlands geol. Unders. 139, 24 pp.

Dawes, P. R. 1994: Themes in the promotion of Greenland's mineral potential. Rapp. Gronlands geol. Unders. 160, 22-27.

Dawes, P. R., Larsen, O. \& Kalsbeek, F. 1988: Archean and Proterozoic crust in North-West Greenland: evidence from $\mathrm{Rb}-\mathrm{Sr}$ whole-rock age determinations. Can. J. Earth Sci. 25, 13651373.

Frisch, T. \& Dawes, P. R. 1982: The Precambrian Shield of northernmost Baffin Bay: correlation across Nares Strait. In Dawes, P. R. \& Kerr, J. W. (ed.) Nares Strait and the drift of Greenland: a conflict in plate tectonics. Meddr Gronland Geoscience $\mathbf{8}$, $79-88$.

Frisch, T. \& Hunt, P. A. 1988: U-Pb zircon and monazite ages from the Precambrian Shield of Ellesmere and Devon islands, Arctic Archipelago. Pap. geol. Surv. Can. 88-2, 66-70.
Koch, L. 1920: Stratigraphy of Northwest Greenland. Meddr dansk geol. Foren. 5(17), 78 pp.

Koch, L. 1933: The geology of Inglefield Land. Meddr Gronland 73, 1(2), $38 \mathrm{pp}$.

Minex, 1995a: Exploration rush reaches Greenland. Greenland MINEX news 8, 1-2.

Minex, 1995b: Exciting results from AEM Greenland 1994. Greenland MINEX news 7, 1-3.

Peel, J. S., Dawes, P. R., Collinson, J. D. \& Christie, R. L. 1982: Proterozoic - basal Cambrian stratigraphy across Nares Strait: correlation between Inglefield Land and Bache Peninsula. In Dawes, P. R. \& Kerr, J. W. (ed.) Nares Strait and the drift of Greenland: a conflict in plate tectonics. Meddr Gronland Geoscience 8, 105-115.

Sharp, G. 1991: Gossan search on Inglefield Land, North West Greenland. Unpubl. report, RTZ Mining and Exploration Limited, 22 pp.

Steenfelt, A. 1993: Geochemical mapping - Progress in Greenland. J. Geochem. Explor. 49, 5-13.

Steenfelt, A. \& Dam, E. in press: Reconnaissance geochemical mapping of Inglefield Land, North-West Greenland. Geol. Surv. Denmark and Greenland, Report 1996/12, 74 pp.

Stemp, R. W. \& Thorning, L. 1995a : Airborne electromagnetic and magnetic survey of Inglefield Land, North-West Greenland. Results from project AEM Greenland 1994. Open File Ser. Grønlands geol. Unders. 95/1, 45 pp.

Stemp, R. W. \& Thorning, L. 1995b: A new airborne electromagnetic and magnetic survey of Inglefield Land, North-West Greenland: Project AEM Greenland 1994-1998. Rapp. Grønlands geol. Unders. 165, 64-68.

Troelsen, J. C. 1950: Contributions to the geology of Northwest Greenland, Ellesmere Island and Axel Heiberg Island. Meddr Gronland 149(7), 85 pp.

B. T. \& P. R. D., Geological Survey of Denmark and Greenland, Copenhagen 